\title{
The Original Distribution of Bois D'Arc. Part I: Texas
}

David H. Jurney

Mercyhurst College

Follow this and additional works at: https://scholarworks.sfasu.edu/ita

Part of the American Material Culture Commons, Archaeological Anthropology Commons, Environmental Studies Commons, Other American Studies Commons, Other Arts and Humanities Commons, Other History of Art, Architecture, and Archaeology Commons, and the United States History Commons

Tell us how this article helped you.

This Article is brought to you for free and open access by the Center for Regional Heritage Research at SFA ScholarWorks. It has been accepted for inclusion in Index of Texas Archaeology: Open Access Gray Literature from the Lone Star State by an authorized editor of SFA ScholarWorks. For more information, please contact cdsscholarworks@sfasu.edu. 


\section{The Original Distribution of Bois D'Arc. Part I: Texas}

Creative Commons License

(c) (i) (8)

This work is licensed under a Creative Commons Attribution-NonCommercial 4.0 International License 


\title{
THE ORIGINAL DISTRIBUTION OF BOIS D'ARC. PART I: TEXAS
}

\author{
by \\ David $H$. Jurney \\ Mercyhurst College, DeSoto, Texas
}

Early historical explorations of the American frontier discuss many tree species and their uses, yet rarely mention bois d'arc (Maclura pomifera). Several important early expeditions sent by President Thomas Jefferson into the southwestern frontier provide the first evidence for the natural and culturally influenced range of the species. Bois d'arc was important in the trade of Native Americans, specifically used for bow wood.

As early as 1804, John Sibley and Merriwether Lewis reported to President Jefferson about bois d'arc, drawing on information derived from transplanted saplings and reporting that the source was ca. 300 miles away (i.e., along the Red River?; see Flores 1985:114). John Sibley, a temporary United States Indian Agent along the Red River in the early nineteenth century, reported a source of bois d'arc wooden bows among the Caddos of the Red River. With these bows they conducted a lively trade among Plains and southeastern Indian groups (Gregory 1973; Webb and Gregory 1978).

The Dunbar and Hunter Expedition along the Ouachita River in 1804-1805 was the first known scientific documentation of bois d'arc on the North American landscape. Their observations and collections were of trees apparently transplanted from more distant sources, as reported by their guides (McDermott 1963). On 20 November 1804 , during discussion of potential and actual uses of various plants for dyes, McDermott (1963:94) states that "at this point in his official report (p.34) Hunter wrote:

This brings to recollection a tree called Bois d'Arc (Bow wood) being very elastic and used by the Indians to make their bows. It is more frequently called Bois jaune (Yellow Wood) used by them and the inhabitants as a dye.

This tree resembles the Orange, grows about 15 feet high, bears a yellow fruit in appearance somewhat between a Shaddock \& a large orange with a rough yellow skin, $\&$ in the inside, seeds in divisions of a pulpy substance resembling the orange tho not so juicy. It is deciduous, grows in abundance on the Red River and on the banks of the little Missouri, a principal branch of the Ouachita. It will grow in the middle and southern states." (McDermott 1963:94).

"Bois d'Arc (Bow-wood) or yellow wood said to resemble fustic: it is extremely elastic, and used by the Indians for bows and arrows, from whence it derives its name. This is a very handsome ornamental tree; its foliage possesses the brilliancy of that of the orange tree, which it greatly resembles in summer, but it is not an evergreen. It grows to the size of a foot or more in diameter; its flowers are said to be white and are followed by a fruit which grows to the magnitude of an Ostrige's (sic) egg and nearly the colour and brilliancy of pale gold; the bark of the tree is also yellowish and scaly in the manner of the dogwood bark: its branches are numerous crossing each other and armed with short strong thorns; it would probably make beautiful strong and durable hedges. The fruit contains many seeds resembling, but larger than, those of the orange, but without any pulp or juices: I have seen one of the trees six inches in diameter, from which I procured some[s] Cions and cuttings with the view of propagating the tree. Some imperfect attempts have been made to dye with it; it is expected that it may furnish a yellow [The yellow dye is soluble, and readily available (Brown and Panshin 1940:471-472)]; upon the whole this tree may be expected to be a great acquisition being highly ornamental, and perhaps may serve as a stock, upon which to graft the orange, lemon, \& c" (McDermott 1963:121).

On 11 January 1805 , returning down the Ouachita, Hunter reports: 
"Our pilot informs us that about 26 leagues up the little Missouri at the Fork of Antoine [i.e., juncture of Pike, Clark, and Nevada counties, Arkansas] on the lower and [word illegible] side upon a bayou that runs up to the hills... 5 leagues above the fork Antoine are to be seen many trees called Bois jaune or Bois d'Arc (yellowwood) or Bow wood, which grow about 15 or 20 feet high... The wood is of a reddish orange colour, \& gives a fine yellow dye; this tree resembles the chinquapin tree in external appearance, bears in the fall a fruit resembling an Orange but twice as large filled with seeds, this tree has a very knotty scrubby appearance.

Perhaps it is the famous tree which yields the yellow dye [held] in so much in esteem in Europe \& reckoned so valuable and rare, capable of dying the finest scarlet - Mr. Le Fevre gave the same account of this tree" - (McDermott 1963:111).

M. Le Fevre was another acquaintance on the trail below Fort Miro, who, in party with ten Indian hunters, reported that a party of Osages from the Arkansas River settlements had killed ten Cherokees (McDermott 1963:110). On 24 January 1805 the same is mentioned - "Mr. Dunbar has received (20 January) a few cuttings, suckers \& seed balls or fruit of the famous yellow dying (sic) tree from the little Missouri which had been transplanted on the Ouachita at the last settlement" (McDermott 1963:114). This settlement with transplanted bois d'arc is estimated to have been ca. 20 leagues upstream from Fort Miro, therefore the northeasternmost of the original distribution of transplanted trees.

Peter Custis provided the first published scientific description of bois d'arc in 1806 (Flores 1984:260). Custis observed a transplanted bois d'arc tree, $30 \mathrm{ft}$ high and a 7-8 ft circumference (ca. $2.5 \mathrm{ft}$ diameter), within one mile of Natchitoches, Louisiana, the southeasternmost observation of transplanted bois d'arc on the Red River. Custis returned the fruit by preserving it in whiskey and sent attached samples of branches and twigs, but could not name it as a new species because it was not in flower. Custis observed the first native trees above the "second" Little River (i.e., Kiamichi?), tributary to the Red River in today's southeastern Oklahoma. He reported that the major source was a tributary stream farther up the Red River called Bois d'Arc; and attributed all occurrences east of this area to transplanted trees around old Caddo villages (Flores 1984:261, 1985:114). Unfortunately, streams of this name are known from both sides of the Red River.

Anthony Glass, traveling overland from Natchitoches to the Wichita villages on the upper Red River in 1807, first observed extensive stands of native (?) bois d'arc, helping to fix the potential original range. The first record was of large quantities on two creeks (e.g., Auds Creek, Hickory Creek and its head Chick Creek) in Lamar County, Texas (Flores 1985:114). Beyond this was Bois d'Arc Creek with the most extensive stands of bois d'arc in Fannin County, reportedly a favorite beaver stream used by French trappers (Flores 1985:114). Glass described bois d'arc as "the most elastic wood in the world" and described the use of it for bows by Wichitas (i.e., Tayovas), where arrows were "propelled completely through bison," or even war captives (Flores 1985:60). On the basis of these descriptions, Flores (1985:114) states that the native distribution of bois d'arc centered on a 200 mile zone north and south of the Red River, from the blackland prairie to the western crosstimbers of Texas and Oklahoma. This area appears to have been an ideal ecological setting for the native tree - interfingered riparian forests of the blackland prairie.

\section{BOIS D'ARC ECOLOGY}

\section{General Land Office Surveys}

The original United States land surveyors kept records and notes which provide a range of information pertaining to the natural environment and cultural history of the radiating American Frontier. The United States Congress established a rectangular grid survey system for the sale of
Public Domain by the General Land Office in 1785. This created a series of Townships generally six miles long on each side, subdivided into 36 one-mile square sections to cover the Public Domain confiscated from the Indians. Township and section corners were marked, from which two to four bearing (i.e., witness) trees were noted and blazed, legal landmarks for the establishment 
of the corners' provenance. The common species names of these trees were recorded, along with their diameters, directions, and distances from said mark. Line trees at ca. 1/4 mile intervals were also blazed and recorded. In 1956, Bourdo published a careful review of the potential uses of rectangular land surveys for the quantification of vegetation. In the review, he noted particular sources of bias and potential error or fraud that should be guarded against (Bourdo 1956:757). Subsequently, botanists have successfully performed reconstructions of soil and plant relationships in presettlement forests (Hushen, Kapp, and Bogue 1966:197) and mapped the invasion of some tree species following settlement (Wuenscher and Valuinas 1967:494). Exhaustive treatments and critiques of General Land Office vegetation reconstructions can be found in Sears (1921, 1925), Howell and Kucera (1956), Zawacki and Hausfater (1969), Wood (1976), King (1978), and Warren (1982). Detailed discussion of statistical applications using rectangular grid sampling is less relevant here, because the Texas GLO data for bois d'arc are derived from the "metes and bounds" land surveying system.

The first United States Public Domain surveyed was in the Ohio Valley, continuing in a wave-like fashion as the frontier moved westward into Indiana, Illinois, and beyond (Matousek 1971:2). Surveys in the Indian Territory (e.g., Oklahoma) were divided into several periods, with some 1830 s and 1840 s Indian Boundary surveys. The Chickasaw Cession was surveyed in the 1870s, and northern and central portions of the state were run by quarters before the land runs of 1889 and 1893. Most subdivisional surveys began in the 1890 s.

Texas contained some rectangular land surveys (e.g., Peters Colony, northern Texas); however, the township and range meridians were not preserved, and all records were destroyed (Connor 1959). The granting and sale of the Texas Public Domain operated in a wave-like fashion, with land in the earliest settlements (i.e., Spanish and Mexican grants) first to be surveyed in the late part of the 18th century and early part of the 19th century. However, a quite different land system, based on metes and bounds and measured in the "Spanish" vara $(1$ vara $=331 / 3$ inches, 1 vara $=0.84667$ meters, with historical variations across the Old and New Worlds), was employed in Texas.
Spanish colonial laws for North America during the 1700 s were designed to provide land only to Spanish citizens. Some Americans began to take advantage of this policy by immigrating into Spanish territory. For instance, Moses Austin immigrated into Spanish Louisiana (i.e., today's Missouri) in 1797, renounced his American citizenship, developed a strong relationship with Spanish colonial authorities, and acquired an Empresario contract to settle Texas (Haley 1985:9). This land allocation system allowed the empresario to charge fees from settlers, while still obtaining land in compensation for encouraging their settlement. Other Americans, including surveyors trained in the United States, began to enter into entrepreneurial relationships with Spanish authorities.

Following the Mexican Revolution in 1821, Moses and Stephen Austin gained the opportunity to persuade the new Mexican government to allow the previously planned settlement. A new colonization law was subsequently approved in 1823; each settler received a maximum of a league (4428 acres) for ranching and a labor (177 acres) for cultivation (Blucher 1940:18-19; Haley 1985:17). Approximately 9248 American families settled in Texas prior to its revolution, through Empresarios such as Stephen Austin, Green DeWitt, Hayden Edwards, Benjamin R. Milam, Joseph Vehlin, David G. Burnett, John Cameron, and Lorenzo de Zavala (McKittrick 1918; Shine 1969:14).

Following the Texas Revolution in 1835-1836, the new government had no tax or credit systems and depended solely on land to fund its burgeoning Republic. The Republic of Texas codified a variant of the Spanish and rectangular land systems in 1836, gradually reducing the size of land grants as demands on land increased (Blucher 1940:20-21; Rounds 1941:28-31; Shine 1969:14; McKittrick 1918). From ca. 1838-1850, surveyors and land entrepreneurs began to lay out tracts in selected areas beyond those already granted and secured. Land was subdivided and sold in advance of the actual settlement. Recipients of land grants still had the option of requesting equal division of select riverine or lacustrine frontages, and land surveying focused on the rapid mapping of select land tracts. As settlement density increased (ca. 1850-1870), remaining unclaimed lands were surveyed, filling in odd spaces among earlier grants. 
Despite the different sizes and shapes of the Texas General Land Office Surveys, at each land tract corner the surveyors still recorded and marked "witness" trees, noting the species, cardinal direction, distance (in varas), and diameter (in inches); they also noted that they "raised a mound" to mark legal provenance in prairie areas (Tharp 1940, 1941). Occasionally, the surveyors marked or noted line trees and summarized the quality of land and composition of the understory vegetation. However, not all surveyors recorded all information at every corner, occasionally leaving gaps; and there is a potential for selective bias or fraud on the part of the surveyor. However, by examining many surveys conducted by several individuals over substantial areas (i.e., county or drainage basin), selective individual biases may be minimized, providing a more representative characterization of vegetation communities. However, spatially meaningful indices are not as robust as those which use United States rectangular land survey data (Bourdo 1956:757).

Broad scale vegetation reconstructions in Texas using metes and bounds data have been provided by Jordan (1973) and Weniger (1984), but are generally not pinpointed to specific land tracts; instead witness tree observations are grouped into vegetation communities with arbitrarily defined boundary zones. Schafale and Harcombe (1983) have performed an extensive statistical vegetation reconstruction for Hardin County, Texas. This latter study reveals the potential for developing quantified descriptions of the presettlement forests (i.e., macro- and micro-community levels), and even in some cases prairies, of Texas.

General Land Office data have been employed to provide detailed maps of original plant distributions at the county and project specific levels in Texas (Jurney 1987, 1988a, 1988b; Jurney, Winchell, and Moir 1989; Moir, McGregor, and Jurney 1994). The Direct Gradient (Bourdo 1956) method is employed in this type of vegetation reconstruction. The Texas GLO patent plats are photocomposited with USGS 7.5' quadrangles and soil maps (if available). Original maps are cross-referenced, plotting GLO boundaries on corresponding USGS or soil aerial maps. This process allows direct comparison of soil types, slope, exposure, and drainage settings; these are all used to establish vegetation "boundaries" (Jurney 1987). All land tracts were examined in project-specific areas (i.e., reservoir or federal grasslands). Surrounding these project areas, alternate land tracts were selected in a checker- board-fashion to encompass one or more counties. Unfortunately, we couldn't examine all surveys without great expenditure of time and effort.

The available GLO matrix for this study consists of a total of 759 patents, distributed among four major projects; Richland/Chambers Reservoir (145 patents in Navarro, Freestone, Anderson, and Henderson counties), Joe Pool Lake and greater Dallas metropolitan area (494 patents in Dallas, Tarrant, and Ellis counties), the U.S. Forest Service's Caddo and L. B. Johnson Grasslands (42 patents in Fannin County and 40 patents in Wise County), and Cooper Lake (38 patents in Delta and Hopkins counties). This data base consists of 4804 trees observed from 2468 land corners, with only 740 corners falling in prairie areas where no trees were within visual limits for witness trees. Some surveyors apparently sighted for greater distances in prairie areas to provide witness for the mounds they were erecting.

No bois d'arc witness trees were observed in the GLO sample from Anderson, Henderson, Ellis, Freestone, Navarro, Tarrant, and Wise counties. Cursory examinations of GLO patents on Fort Hood, in Bell and Coryell counties, also located along the blackland prairie in central Texas, have not yielded any observations of bois d'arc on the original land surveys either (Jennifer Stabler, Fort Hood Archaeological Section, personal communication 1994). Counties where named streams or witness tree observations were documented in the GLO notes include Dallas (only along the eastern boundary), Delta, Hopkins, Fannin, Kaufman, Lamar, Red River, and Rockwall. The southern boundary appears to have been southeastern Dallas and southwestern Kaufman counties, or some point down the Trinity River channel. This appears to have been the southern limit of this species, and is more clearly demarcated than the general distribution reported in contemporary historical accounts (Roberts 1881).

All original GLO notes relating to observations of bois d'arc witness trees, or even mention of bois d'arc as a stream name, were re-examined for this analysis. The GLO sample of witness trees includes 38 observations of individual bois d'arc trees, out of a total of 4804 witness trees $(0.8 \%)$. Thirty-two witness trees, five corner trees, and one line tree were recorded as bois d'arc. Ecological observations of these trees, their diameters, distances, and soil associations are presented below. 


\section{Diameter Classes}

Twelve sizes of trees were observed in this sample, ranging from 2 to 30 inches in diameter. The most common size classes (in inches) were $10(n=5), 24(n=3)$, and $12(n=3)$, followed by $30(n=2), 8(n=2), 6(n=2), 4(n=2)$, and 3 $(n=2)$. Single observations were made of 18,13 , 7 , and 2 inch size classes. This broad range of tree size classes indicates a normal population of trees (Bourdo 1956).

The mean bois d'arc stem diameter was 11.65 inches. Tree size does not necessarily correlate with age. A common assumption expressed when people observe trees is that a large tree must be an old tree, and that all virgin timber must be large trees. The GLO notes clearly indicate a range from saplings to large trees. Dendrochronological observations of wooden elements in historic buildings across eastern and central Texas indicate that bois d'arc never exceeded 100 years in age, although they may attain large diameters. All bois d'arc construction elements used in those historic buildings that have been examined across Texas date to the late nineteenth and twentieth centuries.

\section{Densities}

The distances that were recorded by surveyors from each land tract corner to its respective witness trees provide a rough measure of the spatial aggregation of trees. These distances were recorded in varas $(1$ vara $=331 / 3$ inches, or 0.84667 meters) from the point of observation (e.g., legal land tract corner). In the Texas GLO notes, the Spanish vara was used for dispersion, and the English system for the tree diameters. One observation on the East Fork of the Trinity river noted a bois d'arc witness at 250 varas $(211.7 \mathrm{~m})$ "across a lake," and another at 110 varas (93.1 m) across a prairie near a "trace." The recorded distances for the remaining trees are $36,15,14$, $11,10,9,8,7,6,5,4(3), 3,2$ (4), and 1 vara, with five bois d'arc corner trees, and one line tree.

\section{Commensurate Species and Ecology}

Other trees often observed in GLO patents where bois d'arc is recorded provide more information on the ecological setting. Prominent among these are elm, ash, hackberry, red oak, bur oak, cottonwood, and water oak. Other species less commonly associated include post oak, blackjack oak, hickory, box alder (sic), overcup oak, pecan, mesquite, and honey locust.

One bois d'arc tree on Bois d'Arc Creek in Fannin County was described as "washed down in a sluice." One on the East Fork of the Trinity River in Kaufman County was described as "leaning." Many observations along the East Fork of the Trinity River - under today's Lake Ray Hubbard - indicate vast bodies of water, bottomland prairies, and inundated settings.

\section{Soil Associations}

Six clay soil types (e.g., Catalpa, Frio, Kaufman, Miller, Nahatche, and Trinity) and a loamy soil (e.g., Crockett) are associated with these observed bois d'arc trees. All soils but one (e.g., Crockett) are frequently to occasionally flooded floodplain soils. The frequently flooded phase of the Trinity clay contained $52.6 \%$ of the observed bois d'arc, primarily located along the East Fork of the Trinity River in eastern Dallas, western Kaufman, and western Rockwall counties, and the South Sulphur River in northern Hopkins and southern Delta counties.

The frequently flooded phase of the Kaufman clay along the South Sulphur River with $10.5 \%$ and the frequently flooded Catalpa clay along Bois d'Arc Creek in Fannin County with $7.9 \%$ comprise the second most adaptive soils for bois d'arc. The frequently flooded Frio silty clay (5.3\%), occasionally flooded Trinity clay $(5.3 \%)$, occasionally flooded Kaufman clay (5.3\%), and Miller clay (5.3\%) soils comprise the third most adaptive soils. Of these soils, the Miller clay is formed strictly in Red River alluvium. Finally, the frequently flooded Nahatche $(2.6 \%)$, high bottom phase of the Catalpa clay $(2.6 \%)$, and Crockett loam $(2.6 \%)$ soils round out those associated with bois d'arc. The Crockett is an upland soil, which was probably not suitable for the sprouting ecology of bois d'arc. Since the single occurrence on this soil was observed along the Caddo Trace southeast of Paris, Texas (Flores $1985: 114)$, this occurrence may have been a transplanted tree. 


\section{CONCLUSIONS}

According to extensive, and admittedly incomplete, sampling of Texas GLO records, bois d'arc was located in three major areas:

(1) along the East Fork of the Trinity River and one tributary, Rowlett Creek, in Dallas, Kaufman, and Rockwall counties;

(2) along the North Fork Sulphur River and its tributaries Auds and Hickory creeks in Lamar County and the South Sulphur River in northern Hopkins and Delta counties; and

(3) Bois D'Arc Creek, a tributary of the Red River in Fannin and Lamar counties, Texas.

There were no occurrences noted in original surveys west of the Trinity River, in western Dallas, Ellis, Tarrant, or Wise counties, in what has been defined as the eastern and western crosstimbers of Texas. There were no occurrences noted in any surveys along the Trinity River to the south in Navarro, Freestone, Anderson, or Henderson counties.
The ecology of native bois d'arc required frequently flooded to occasionally flooded environmental settings. Thus, the tree's seeds, encased in large fruits, were distributed by water along high water margins. The tree thus would have normally redistributed itself only downstream. There may have been a co-adaptation with beaver-inundated river basins, which may have limited the distribution above primary beaver dams.

Preliminary investigations of the Oklahoma General Land Office surveys, housed at the State Library in Oklahoma City, suggest that significant temporal information may be available on the distribution of bois d'arc. Boundary, meridian, and township surveys appear to have been conducted prior to sectional surveys, potentially providing data on native range as well as transplantation. The species has been noted in Bryan County, and a future paper is planned on this subject, as Part Il, which will include occurrences in Oklahoma.

\section{ACKNOWLEDGEMENTS}

The GLO information was collected and presented in conjunction with several sponsors; including the U.S. Army Corps of Engineers; the Tarrant County Water Control and Improvement District Number One; the U.S. Forest Service, Lufkin; and the Superconducting Super Collider Laboratory. Jennifer Stabler provided informa- tion from her research at Fort Hood, U.S. Army. The earlier researches on the Richland/Chambers and Joe Pool Lake projects were supported by the past Directors of the Archaeology Research Program, L. Mark Raab, James E. Bruseth, and Randall W. Moir.

\section{REFERENCES}

Blucher, Carl F.

1940 Record Investigation Preliminary to Surveying. In Proceedings of the First Texas Surveyor's Short Course, pp. 1723. The General Land Office, Austin. Reprinted by the Texas Surveyor's Association, 1958.
Bourdo, E.A.

1956 A Review of the General Land Office Survey and of Its Use in Quantitative Studies of Former Forests. Ecology 37:754-768. 
Brown, H.P. and A.J. Panshin

1940 Commercial Timbers of the United States: Their Structure, Identification, and Uses. McGraw-Hill, New York.

Connor, Seymour V.

1959 The Peters Colony of Texas. The Texas State Historical Association, Austin, Texas.

Flores, Dan (editor)

1984 Jefferson and Southwestern Exploration: The Freeman and Custis Accounts of the Red River Expedition of 1806 . University of Oklahoma Press, Norman.

1985 Journal of An Indian Trader: Anthony Glass and the Texas Trading Frontier, 1790-1810. Texas A\&M University, College Station.

Gregory, Hiram F.

1973 Eighteenth Century Caddoan Archaeology: A Study in Models and Interpretation. Unpublished Ph.D. dissertation. Southern Methodist University, Dallas.

Haley, James L.

1985 Texas: An Album of History. Doubleday and Co., Garden City, NJ.

Howell, D.L. and C.L. Kucera

1956 Composition of Presettlement Forest in Three Counties of Missouri. Bulletin Torrey Botanical Club 83(3):207-217.

Hushen, T.W., R.O. Kapp, and R.D. Bogue

1966 Presettlement Forest Patterns in Montcalm County, Michigan. Michigan Botanist 5:192-211.

Jordan, Terry G.

1973 Pioneer Evaluation of Vegetation in Frontier Texas. Southwestern Historical Quarterly 76:233-254.

Jurney, David H.

1987 Presettlement Vegetation Recorded in Land Surveyor's Notes. In, Richland Creek Archaeological Project Technical Series, Volume V, edited by David $\mathrm{H}$. Jurney and Randall W. Moir, pp. 211228. Archaeology Research Program, Southern Methodist University, Dallas. 1988a Early Historic Vegetation Zones. In, Historic Farming on the Hogwallow Prairies: Ethno-Archaeological Investigations of the Mountain Creek Area, North Central Texas, Volume 2, compiled by David $\mathrm{H}$. Jurney, Susan A. Lebo, and Melissa M. Green, pp. 333-351. Archaeology Research Program, Southern Methodist University. Final Report submitted to U.S. Army Corps of Engineers, Fort Worth District, Contract No. DACW6384-C-0146.

1988b Early Vegetation Recorded in the General Land Office Surveys. The Record: 50th Anniversary Edition 42(3):170-176.

Jurney, David H., Frank Winchell, and Randall W. Moir

1989 Cultural Resources Overview of the National Grasslands in North Texas: Studies in Predictive Modeling for the Caddo and LBJ Grasslands. Archaeology Research Program, Southern Methodist University. Final Report submitted to the U.S. Forest Service, Lufkin.

King, F.B.

1978 Additional Cautions on the Use of the General Land Office Survey Records in Vegetational Reconstruction in the Midwest. American Antiquity 43(1):99-103.

Kniffen, Fred B., Hiram F. Gregory, and George A. Stokes

1987 Tribes of Louisiana from 1542 to the Present. Louisiana State University Press, Baton Rouge.

McDermott, John Francis (editor)

1963 The Western Journals of Dr. George Hunter, 1796-1805. Transactions of the American Philosophical Society, n.s. 53 (1):114.

McKittrick, Reuben

1918 The Public Land System of Texas, 1823 1910. Madison, Wisconsin.

Matousek, Ladislav

1971 The Beginning of Illinois Surveys. Illinois Libraries, Archive Issue 53(1). Czechoslovak Society of Arts and Sciences in America. 
Moir, Randall, Daniel McGregor, and David Jurney (co-principal investigators)

1994 Cooper Lake Archaeological Investigations at Cooper Lake: 1987 Season. Archaeology Research Program, Mercyhurst College. Final Report submitted to the U.S. Army Corps of Engineers, Fort Worth District.

Roberts, Oran M.

1881 A Description of Texas. Gilbert Book Co., St. Louis, Missouri.

Rounds, W.A.

1941 Some Judicial Decisions Affecting Property Lines. In Proceedings of the First Annual Conference on Surveying and Mapping 1940, pp. 28-31. The General Land Office, Austin. Reprinted by the Texas Surveyor's Association, 1958.

Schafale, M.P. and P.A. Harcombe

1983 Presettlement Vegetation of Hardin County, Texas. American Midland Naturalist 109(2):355-366.

Sears, P.B.

1921 Vegetation Mapping. Science 53:325327.

1925 The Natural Vegetation of Ohio. Ohio Journal of Science 23:139-149.

Shine, Darrell D.

1969 The Story of Texas Lands. The Consultant 14:13-19.

Tharp, B.C.

1940 Trees. In Proceedings of the First Texas Surveyor's Short Course. Reprinted by the Texas Surveyor's Association, 1958.
1941 Preparation of a Tree for Court. In Report of the Second Texas Surveyor's Short Course. Reprinted by the Texas Surveyor's Association, 1958.

Warren, Robert E.

1982 The Historical Setting. In The Canon Reservoir Human Ecology Project: An Archaeological Study of Cultural Adaptations in the Southern Prairie Peninsula, edited by M.J. O'Brien, R.E. Warren, and D.E. Lewarch, pp. 29-70. Academic Press, New York.

Webb, Clarence H. and Hiram F. Gregory

1978 The Caddo Indians of Louisiana. Anthropology Study 2. Louisiana Antiquities Commission, Department of Culture, Recreation, and Tourism, Baton Rouge.

Weniger, Del

1984 The Explorer's Texas; The Lands and Waters. Eakin Press, Austin.

Wood, W.R.

1976 Vegetational Reconstruction and Climatic Episodes. American Antiquity 41(2):206-208.

Wuenscher, J.E. and A.J. Valinuas

1967 Presettlement Forest Composition of the River Hills Region of Missouri. American Midland Naturalist 78(2):487-495.

Zawacki, A.A. and G. Hausfater

1969 Early Vegetation in the Lower Illinois River Valley. Reports of Investigations 17, Illinois State Museum, Springfield.
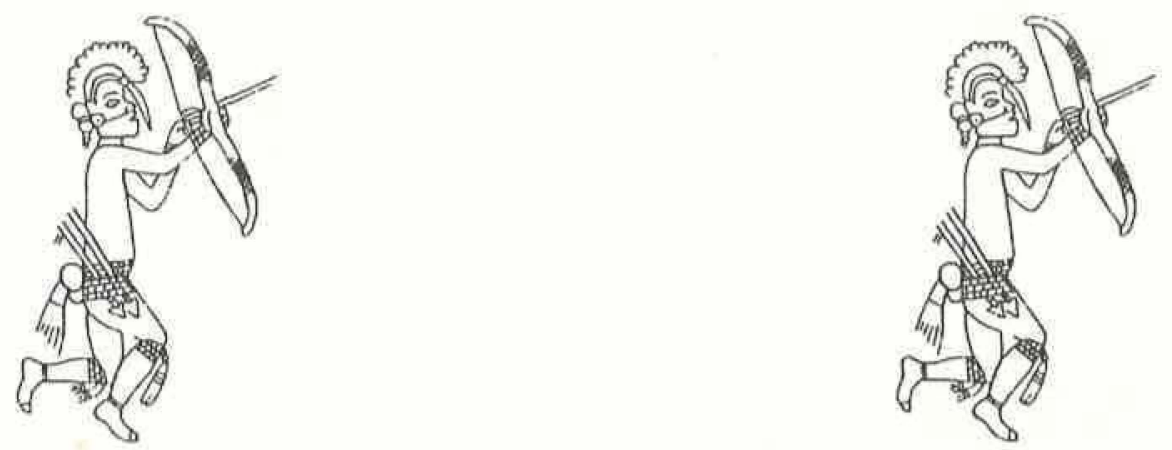